\title{
Depictions and Modelings of the Body Seen in Japanese Folk Religion: Connections to Yokai Images
}

\author{
Manami Yasui \\ The International Research Center for Japanese Studies, Kyoto, Japan \\ Email:m-yasui@nichibun.ac.jp
}

How to cite this paper: Yasui, M. (2017). Depictions and Modelings of the Body Seen in Japanese Folk Religion: Connections to Yokai Images. Advances in Anthropology, 7, 79-93.

https://doi.org/10.4236/aa.2017.72006

Received: February 28, 2017

Accepted: May 6, 2017

Published: May 9, 2017

Copyright $\odot 2017$ by author and Scientific Research Publishing Inc. This work is licensed under the Creative Commons Attribution International License (CC BY 4.0).

http://creativecommons.org/licenses/by/4.0/ (c) (i) Open Access

\begin{abstract}
Hoping to clarify the abundant creative ability that produced Japanese yokai, I have examined depictions and modelings of these supernatural creatures of Japanese folklore. In particular, I have focused on yokai fashioned in the manner of hitotsume kozō, by altering part of the human body. In so doing, I thought that clues to the creation of yokai based on bodily motifs might be found in examples from folk religion of depicting or modeling the body. Accordingly I took up the topic of ema and the folk practice of offering these small wooden boards invested with prayers for recovery from disease and so forth. Among parts of the body drawn on ema, the eyes, hands, breasts, and female and male genitalia are common, but in this contribution I analyze in particular the mode of expression used in ema for eyes, breasts, and female genitalia. As a result, it became clear that the style of drawing seen in ema, of multiple eyes lined up or genitals and breasts depicted in exaggerated fashion, is linked to a considerable degree with the mode of expression used in creating bodily motif yokai. I believe this perspective may contribute to research clarifying views of the body and the creative power of people who produced and enjoyed yokai in the past.
\end{abstract}

\section{Keywords}

Yokai, Views of the Body, Folk Religion, Ema, Japan

\section{Introduction}

Currently, Japan is once again in the midst of a recurrent boom in yōkai, supernatural creatures of Japanese popular culture and folklore. The Yōkai Watch game released for the Nintendo 3DS console in July 2013, and the Pokémon Go game released in July 2016, have gained tremendous popularity centering on 
various countries in Asia and the West. The Japanese word yōkai is now written directly in English as yokai, and Japanese yokai comics and anime are translated in countries throughout the world and can be enjoyed at nearly the same time as their release in Japan. Meanwhile, remarkable contributions to research by Komatsu $(1994,2008)$, the preeminent figure on yokai, and recently young scholars such as Kagawa (2005) and Iikura (2010) and Iikura \& Ichiyanagi (2016), have stimulated the advancement of yokai in popular culture. In America, Michael Foster $(2009,2015)$ has been developing a unique treatment of yokai within the context of Japanese history and culture.

I have previously made considerations of graphic depictions and modelings of yokai, from a desire to clarify the rich powers of human imagination which have given birth to this notion (Yasui, 2014, 2015, 2016, 2017). Among depictions of yokai, there are many which have been fashioned by altering parts of the human body, such as rokurokubi (Figure 1) and hitotsume kozō (Figure 2), and taking an interest in yokai with this type of body, I have continued to conduct research from the perspectives of Japanese folklore and anthropology.

In researching yokai, I pay heed to their bodies for the following reasons. First, from the perspective of "bodies targeted by yokai," I thought it possible to clarify people's perceptions of the body. Formerly, illness and injury were thought to arise from evil spirits or yokai entering or attacking the body, and in Japan's Medieval period (13th - 16th centuries) in particular, it was thought that

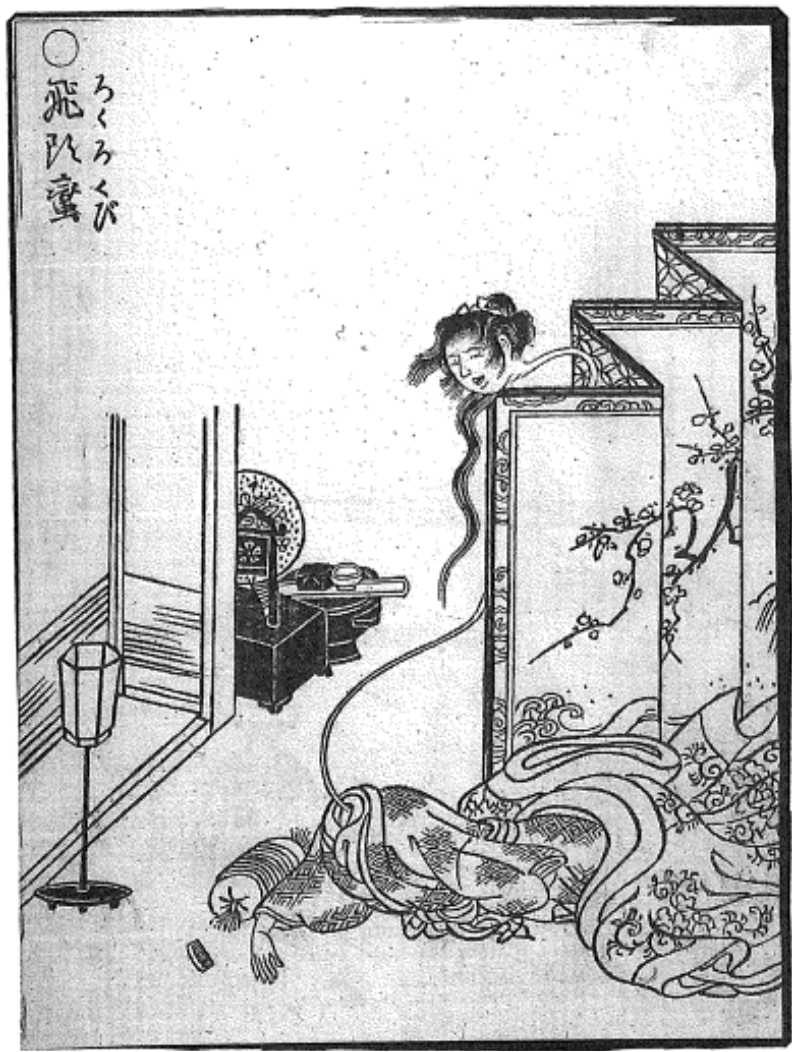

Figure 1. Rokurokubi, illustrated in Toriyama Sekien's Gazu Hyakki Yagyō of 1776. (From Toriyama [2005: p. 42]). 


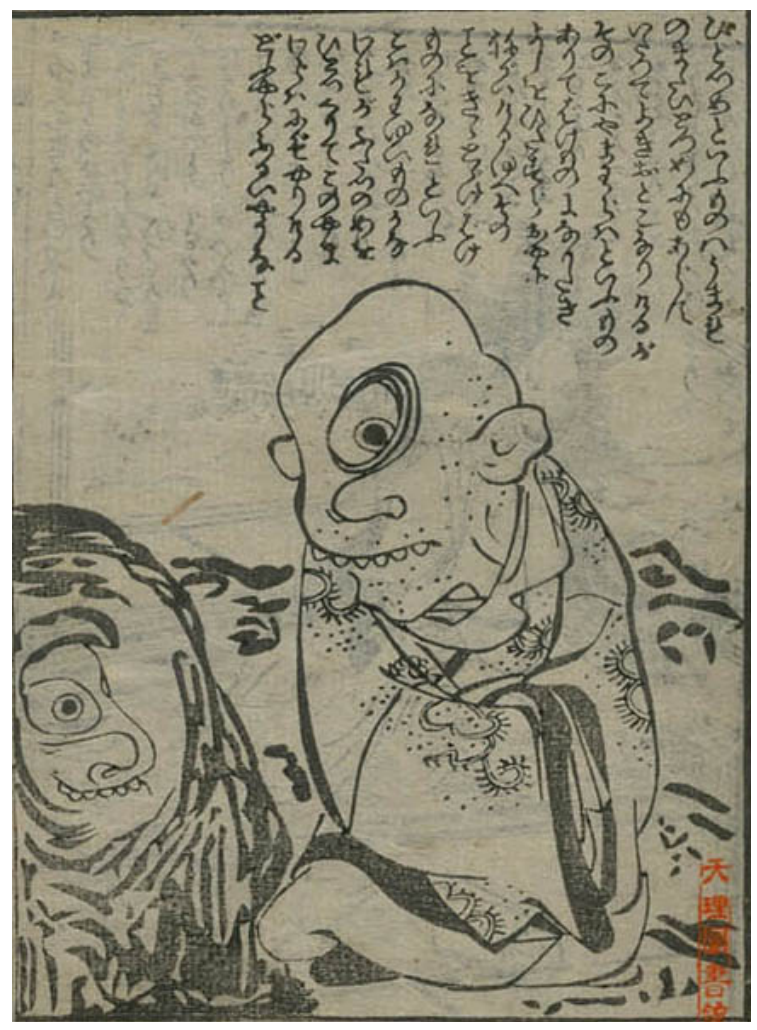

Figure 2. Hitotsume kozō, illustrated by Utagawa Toyokuni in Sakuragawa Jihinari's Bakemono Haruasobi [Monsters' Spring Play] of 1793. In the collection of Tenri Central Library. (From Tenri University Department of History and Culture [2016, frontispiece]).

evil spirits would invade through the pores of one's skin (Kuroda, 1986). As preventive measures, people would protect their bodies by placing amulets on those parts thought vulnerable, as buffers to hide them from or ward off harm. From an analysis of folkloric beliefs and traditions related to "bodies targeted by yokai" and "bodies protected from yokai assault," it should thus be possible to clarify how people perceived the body (Yasui, 2014).

Second, I believed it would be possible to find clues, among examples in folk religion of graphic depictions and modelings of the body, to the generation of yokai through altering parts of the human body. Clarification of this is precisely the theme of the current contribution. To that end, I focus in Section 3 on koema, small votive pictures drawn on boards, in which commoners of the Edo period invested all manner of wishes, and analyze expressions of bodily parts drawn therein. This stems from my hypothesis that the mode of expression in depictions and modelings of the body in folk religion would be fundamentally linked with that of yokai images related to the body.

Third, I take the position of approaching yokai through a discourse of the body with reference to the perspective held by Corbin, Courtine, and Vigrello (2005), who edited History of the Body, that the body should indeed be taken as a boundary and regarded as an arena in which various phenomena of an age are distilled. 
Keeping these points in mind, I would like to consider the generation of yokai based on the human body as motif, from depictions and modelings of parts of the body in folk religion.

\section{Bodily Motif Yokai}

\subsection{Examples of Bodily Motif Yokai}

Among images of yokai, there are many that were generated by altering or exaggerating parts of the body. The rokurokubi and hitotsume kozo mentioned above are two examples. The rokurokubi is a yokai with an elongated neck (Figure 1), and the hitotsume kozo has a single central eye or is missing one of its eyes (Figure 2). Both images shown here were drawn in the latter half of the eighteenth century.

It is of great interest that yokai related to the eyes, such as dodomeki (Figure 3) and mokumokuren (Figure 4), appear in Gazu Hyakki Yagyō (Illustrated Night Parade of One Hundred Demons) and Konjaku Hyakki Shūi (Supplement to "The Hundred Demons from the Present and the Past"), volumes drawn by the Edo period yokai artist Toriyama Sekien (1712-1788) who will be discussed later.

When did the practice of drawing such yokai based on bodily motifs begin?

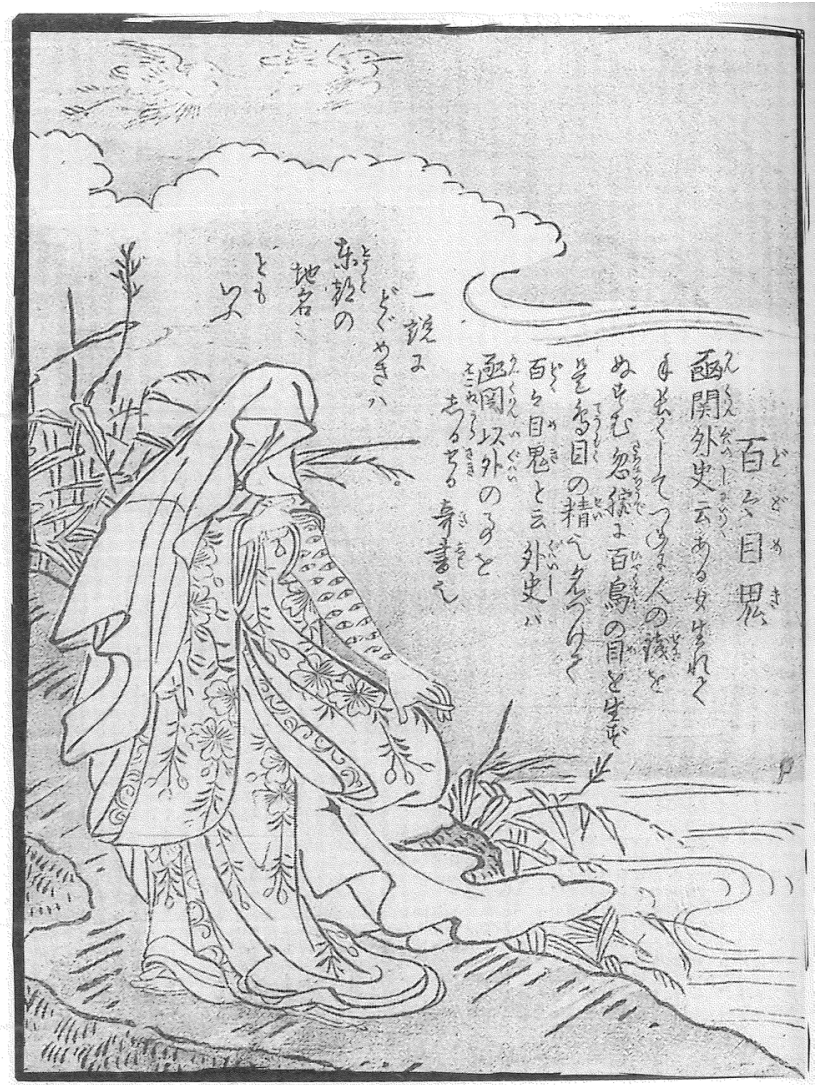

Figure 3. Dodomeki, illustrated in Toriyama Sekien's Konjaku Gazu Zoku Hyakki [Illustrated One Hundred Demons from the Present and the Past] of 1779. (From Toriyama [2005: p. 119]). 


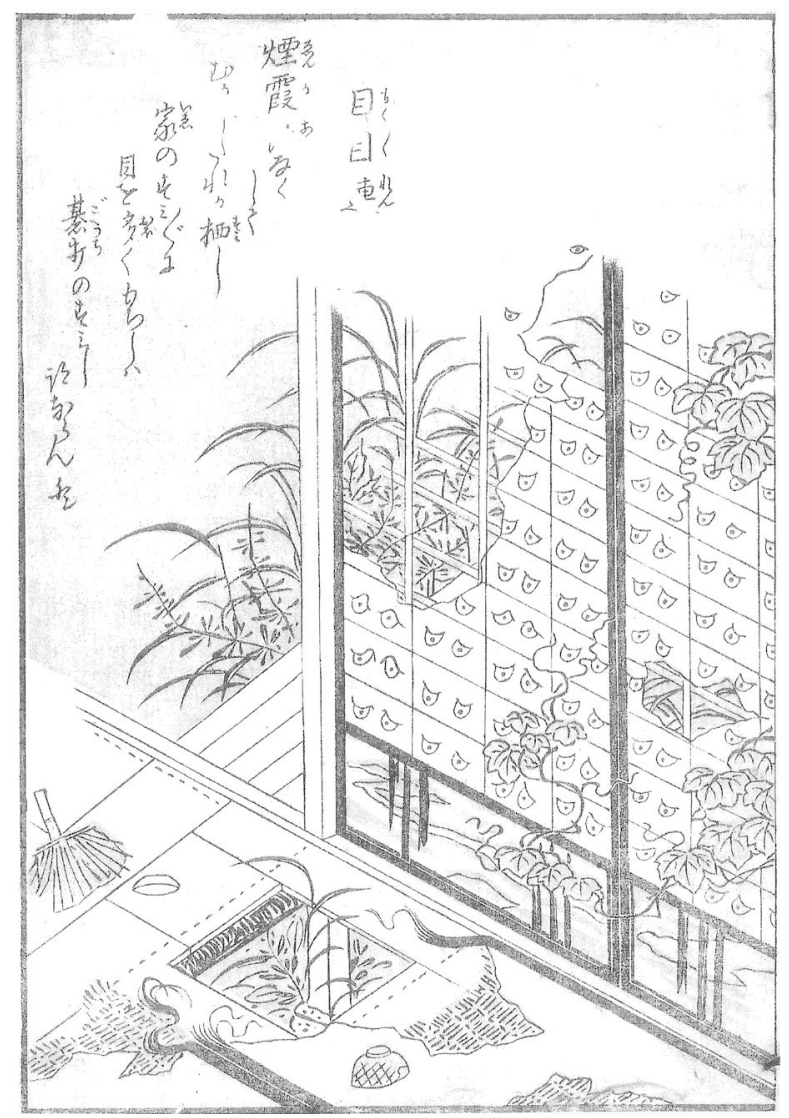

Figure 4. Mokumokuren, illustrated in Toriyama Sekien's Konjaku Hyakki Shüi [Supplement to "The Hundred Demons from the Present and the Past”] of 1781. (From Toriyama [2005: p. 180]).

\subsection{The Generation of Yokai Imagery}

Incidentally, yokai did not necessarily have clearly defined forms or figures. Regarding the circumstances by which yokai came to be depicted, we have superb research by Komatsu and Kagawa. In his analysis of a picture scroll produced in the Muromachi period, Hyakki Yagyō Emaki (Night Parade of One Hundred Demons Picture Scroll), in which many demons and grotesque figures gather or parade through the city streets at night, Komatsu (2008) notes that nearly all of the images are yokai consisting of anthropomorphizations of daily utensils. Accordingly he states that "At the very least, in the background of thinking about yokai in the Medieval period, we should understand there was the idea of the 'anthropomorphization, 'zoomorphization,' or 'demonization' of not only utensils, but all things in existence" and emphasizes that "the technique of 'anthropomorphization' in tales and drawings is of extreme importance when considering yokai" (Komatsu, 2008: pp. 202, 193-194).

By the Edo period, from developments in printing technology it had become possible to disseminate the same information in great volumes simultaneously, through color prints and books printed from woodblocks. These advances in printing technology at once broadened the yokai sphere, contributing to the birth of a great variety of yokai (Yumoto, 2003). 
In his Edo no Yōkai Kakumei (The Edo Yokai Revolution), Kagawa (2005), citing Foucault, points out that the latter half of the eighteenth century's fascination with natural history brought with it a tremendous change to the yokai realm. Namely the newfound interest in verbally articulating and classifying natural phenomena also came into operation when creating yokai as well, resulting in the production of illustrated references such as Toriyama's Gazu Hyakki Yagyō. Previously, yokai which had been depicted as unnamed grotesque creatures in picture scrolls came to be individually named in new illustrated references such as Gazu Hyakki Yagyō, and were circulated with commentaries attached.

The bodily motif yokai introduced above (Section 2.1) can also be said to have been created in the midst of this trend for rendering depictions of things. In order to consider the genesis of these yokai having bodily motifs, I would next like to focus on folk religion and introduce some examples of the depiction and modeling of the body.

\section{Depictions Seen in Folk Religion}

\subsection{Ema Drawn with Commoners' Wishes}

From olden times in Japan, when people fell ill or were injured, the folk religious practice of drawing the afflicted portion of the body on a small wooden board and offering it at a Shinto shrine in hopes of a cure has been popular. Such very small boards, called koema (small ema), conveniently sized at around $10 \mathrm{~cm}$ by $15 \mathrm{~cm}$ and between $5 \mathrm{~mm}$ and $1 \mathrm{~cm}$ thick, came to be hung up on wooden sanctuaries of shrines or at designated spots on the precincts. Regarding ema and koema, I would like here to summarize briefly the research of Iwai (1974). Ema are of two types, the smaller sized koema that could be readily hung up with string, and another called oema that had become both very large and splendidly made, and were used to decorate shrine buildings in the manner of a plaque or signboard. Ema are held to have originated as items fashioned in lieu of the offering of a horse, the proper mount for a deity, and at first they were drawn with a picture $(e)$ of a horse $(\mathrm{ma})$. Subsequently, the making of a great variety of koema, in which the various prayers of commoners for recovery from diseases were invested, is seen to have developed in the Bunka and Bunsei eras (18041830) of the Edo period, when the culture of townsmen flourished. At that time, professional ema artists made their appearance, and all manner of commoners' wishes came to be depicted.

The folk religious practice of offering ema continued thereafter, and in addition to prayers for success at the matching or separation of couples, recovery from diseases, safe childbirth and so forth, there were many wishes regarding childrearing, such as prayers that children's dislike of baths or haircuts would be cured, that their crying at night would stop, for their quiet sleep and the like, with the content of the wishes thus becoming quite concrete and particular. The custom of offering koema continues today, with prayers for success in life or in entrance exams, for good health, and so forth being common. 
Bit by bit, I have been collecting examples of koema drawn with parts of the body by actually visiting shrines and temples to purchase these items, and from published research and exhibition catalogs. As noted above, since koema are invested with a variety of wishes, portrayals of body parts make up only a portion of them. Further, it became clear that the parts of the body which are drawn are limited to a certain extent, with eyes, hands, and breasts being common, in addition to which there are also those depicting male and female genitalia, and so forth. Among those for the hands, patterns having both hands lined up are common, and they include items modeled in the shape of the outlines of hands (Figure 5). Now I would like to turn to an examination of ema drawn with eyes, breasts, and female genitals.

\subsection{Koema for Eyes}

Among koema are many items wishing for recovery from eye afflictions. Back in the day of living conditions where the lighting was dim and the houses filled with smoke from wood stoves used for cooking, and with knowledge about hygiene lacking and nutrition insufficient, many people suffered from eye diseases such as trachoma or styes. A koema illustrating such conditions (Figure 6) was offered at a shrine to Yakushi (the Medicine Buddha) on the precincts of Bannaji, a temple of the Shingon sect's Dainichi branch in the city of Ashikaga, Tochigi prefecture. The depiction of eight eyes is a play on the words for "eight eyes," using the same pronunciation as "afflicted eye" (yanme). The hiragana character め (me, "eye") is also written.

Among this type of ema there are many items having two such characters written in symmetrically opposite fashion to substitute for a pair of eyes, or the same character or an eye drawn repeatedly to match a person's age, or in sets of

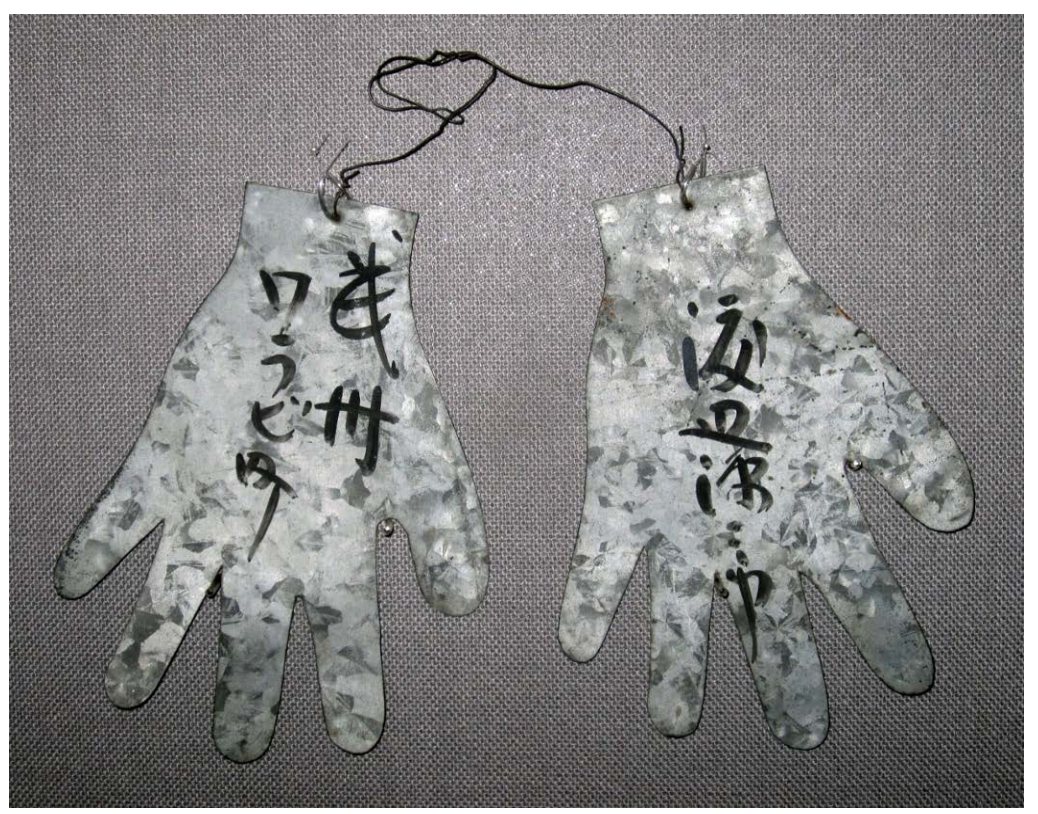

Figure 5. An offering drawn with the outlines of hands, from the city of Warabi, Saitama prefecture. (In the collection of Tenri University Sankokan Museum.) 


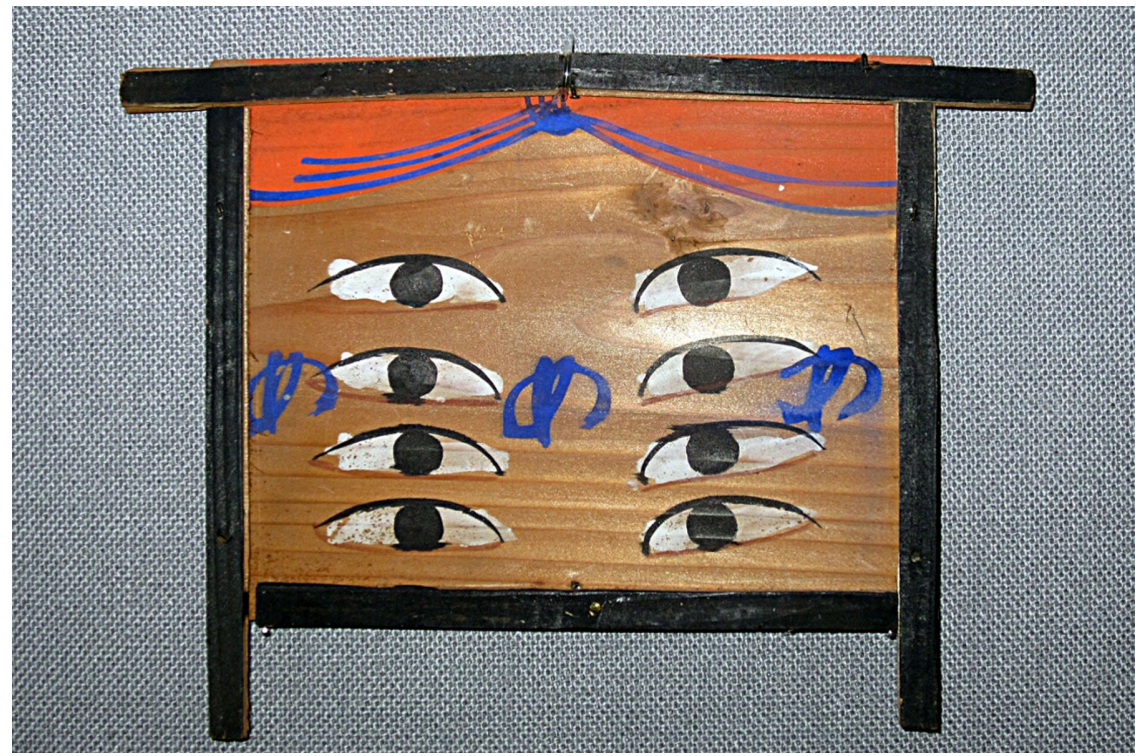

Figure 6. A koema drawn with yanme (eight eyes), from a shrine to Yakushi (the Medicine Buddha) at Bannaji temple, in the city of Ashikaga, Tochigi prefecture. (In the collection of Tenri University Sankokan Museum.)

8, 12, or 16 items (Iijima, 2001). Perhaps it was thought that thus depicting multiple numbers of eyes on koema would increase their efficacy.

The reason this item was offered at a shrine of the Medicine Buddha is because this figure is regarded as the Buddha of healing, and also because the first of the Medicine Buddha's Twelve Vows is "To illuminate countless realms with his radiance," meaning that light emanating from his being will shine over the world, so he was accordingly widely revered among the people as the deity of eye disease (Iijima, 2001: p. 85).

\subsection{Koema for Breasts}

I next treat ema related to maladies unique to women. Figure 7 shows koema from subsidiary shrines outside the precincts of Kasuga Taisha shrine, one from Shirachi shrine inscribed "ailments of the upper half of the female body" and the other from Akachi shrine labeled "ailments of the lower half of the female body." Both can be obtained at Meoto Daikokusha, a subsidiary shrine on the precincts of Kasuga Taisha in the city of Nara, and even now these items are all drawn by hand. The former is for illnesses that afflict women from the waist up, and perhaps because these included mastitis and breast cancer, they are expressed with pictures of breasts. In contrast, the latter is for women's illnesses from the hips down, and it is noteworthy that this is shown with a woman's kimono to avoid directly drawing female genitals.

Figure 8 is a koema with a three-dimensional expression of the breasts rather than a drawing on a flat surface. This is not for recovery from disease, but an ema wishing for a good supply of mother's milk. In former times, when powdered milk was not available as a substitute, as it was very difficult to care for an infant when its mother's milk did not flow, production of a good supply of milk 

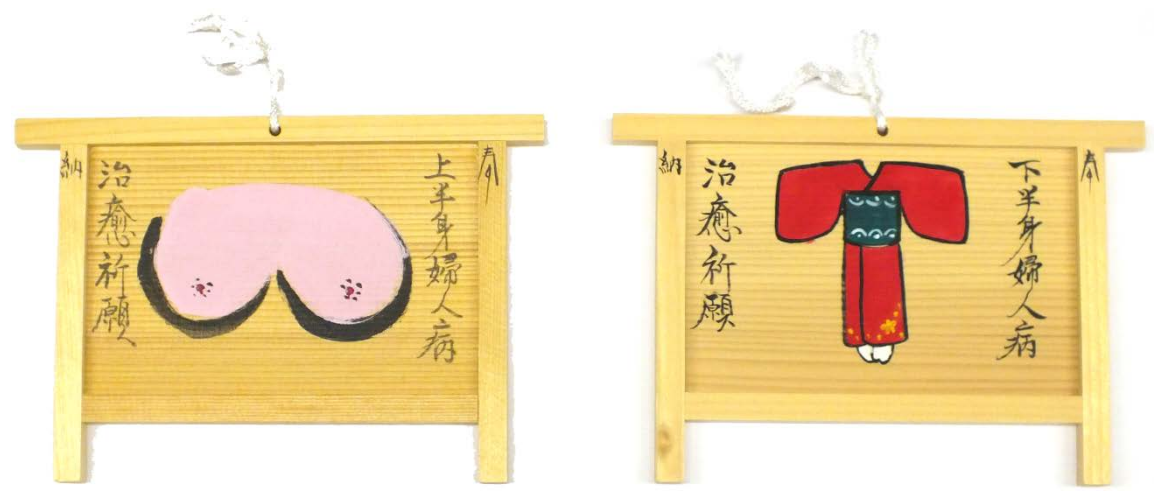

Figure 7. Koema related to maladies unique to women, from subsidiary shrines outside the precincts of Kasuga Taisha shrine in the city of Nara. Left. for "ailments of the upper half of the female body," from Shirachi shrine. Right: for "ailments of the lower half of the female body," from the Akachi shrine. (Photos by the author.)

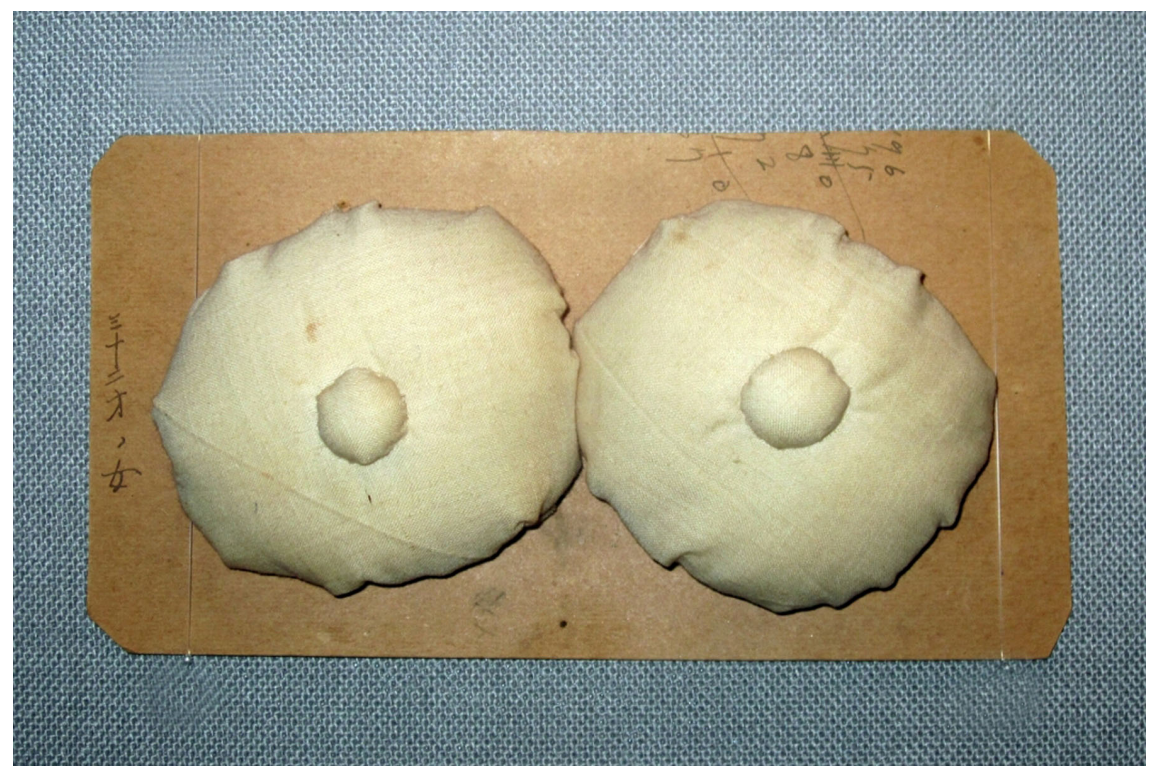

Figure 8. An offering in the shape of breasts, from Ikeda Kannonji temple in the city of Kakogawa, Hyogo prefecture. (In the collection of Tenri University Sankokan Museum.)

was an earnest prayer for a mother. For that reason items sewn in the shape of breasts were attached to a board or stiff paper and given as offerings. When the period of nursing had finished, the same manner of breast ema would be given as an expression of gratitude.

Figure 9 is a koema from the Kannon shrine at Bandaiji temple (Rinzai sect, Myōshinji branch) located at Tomo no ura in the city of Fukuyama, Hiroshima prefecture. The town of Tomo on the southern end of the Numakuma peninsula prospered from the Ancient into the Early Modern periods as a strategic point on the Seto Inland Sea, and from its modern day beautiful scenery it was chosen as the stage for Miyazaki Hayao's anime film Ponyo on the Cliff by the Sea. The Kannon shrine at Bandaiji stands at the tip of the Abuto promontory, which forms a precipitous cliff (Figure 10). Its founding is held to be in the year 986, when an eleven-headed Kannon was enshrined there in prayer for safe passage at 


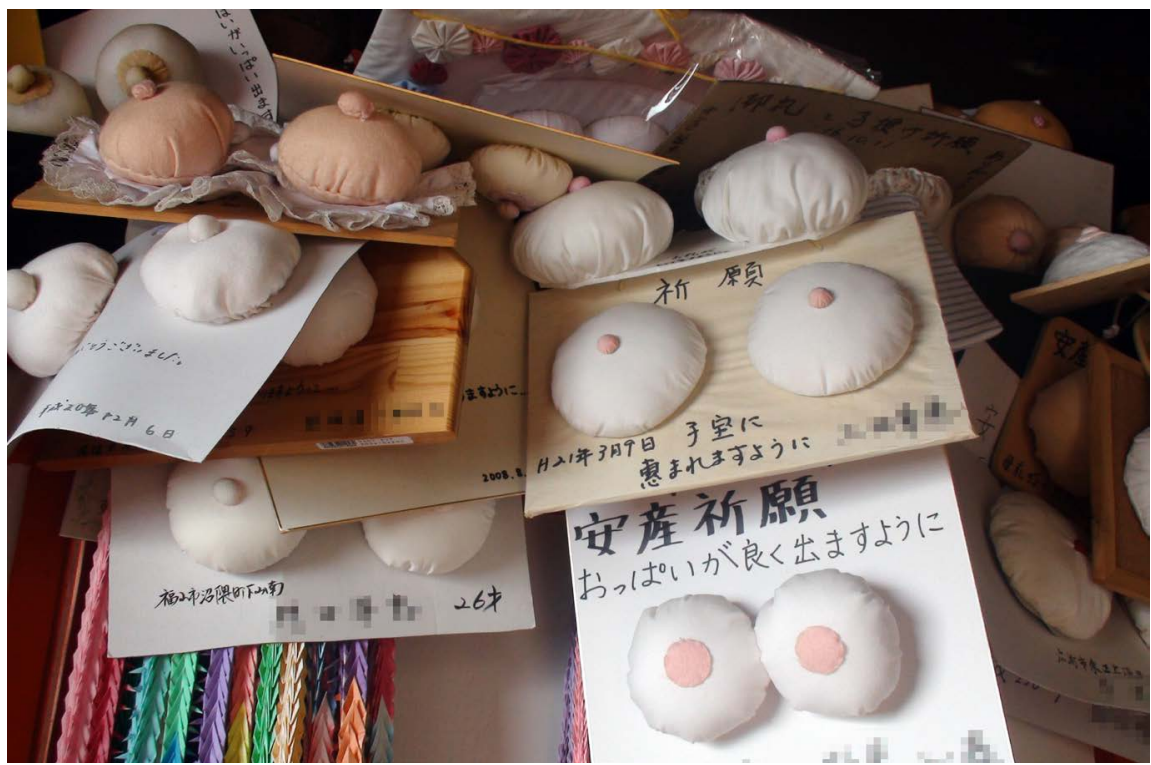

Figure 9. Offerings in the shape of breasts, in prayer for a sufficient supply of milk, from the Kannon shrine at Bandaiji temple, located at Tomo no ura in the city of Fukuyama, Hiroshima prefecture. (Photo by the author.)

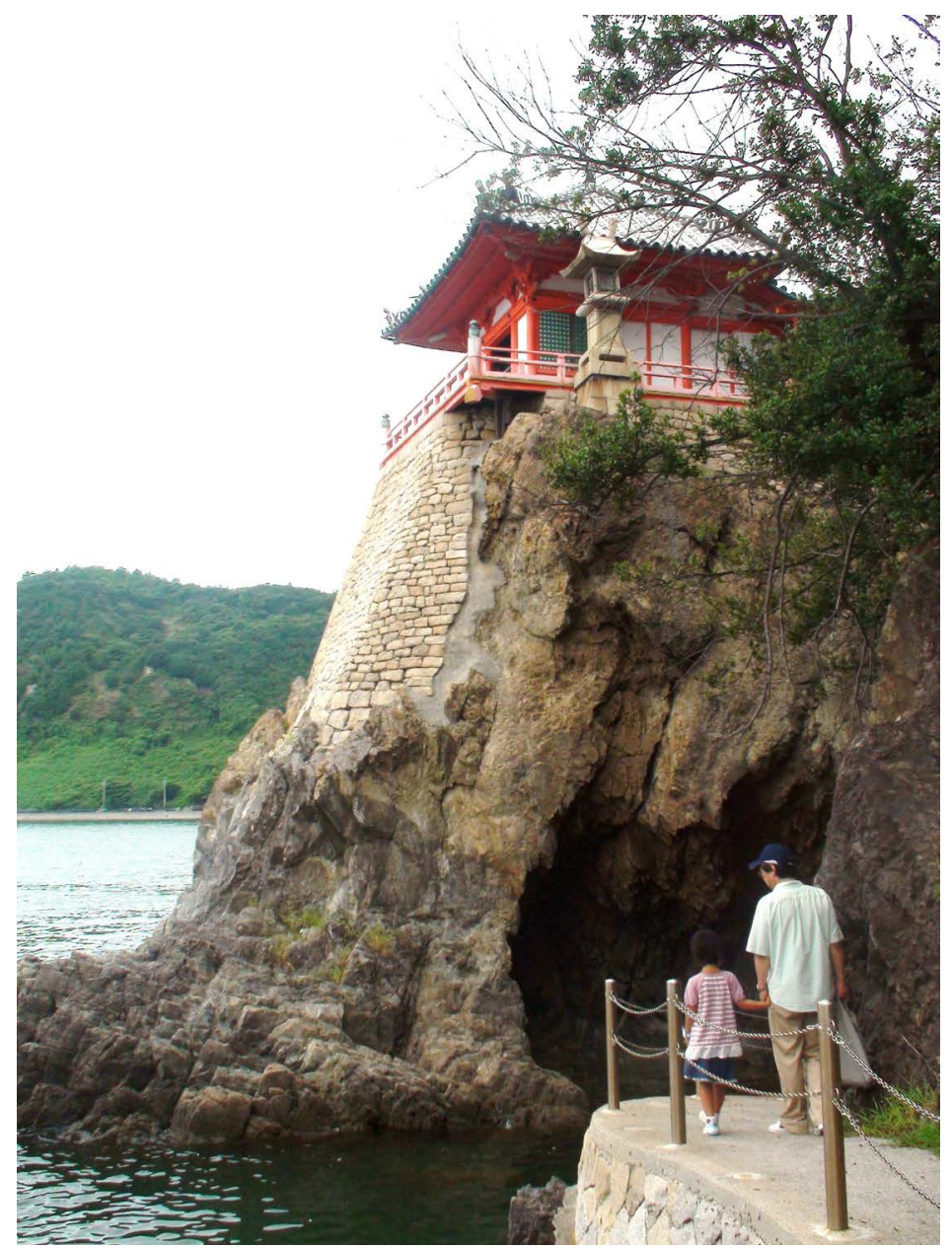

Figure 10. The Kannon shrine at Bandaiji temple, at the tip of the Abuto promontory at Tomo no ura in the city of Fukuyama, Hiroshima prefecture. (Photo by the author.) 
sea, and subsequently it came to be revered broadly as the deity of pregnancy and safe childbirth as well.

For this reason, even today women praying for a sufficient supply of milk offer many ema fashioned with sewn objects in the shape of breasts at the Kannon shrine at Bandaiji, as shown in Figure 9. This is because the value of breast milk, which changes in composition in keeping with the infant's development and helps provide various immunities, is being reevaluated in Japan, and many women wish to raise their babies by breast feeding. What we want to note here is that both the koema wishing for recovery from ailments (Figure 7, left) and those seeking a good supply of milk (Figure 8, Figure 9) are expressed in the same form of depictions or modeling of breasts despite the specific content of the prayers being different. I wish to emphasize that differing wishes, in order to be conveyed through the most readily understandable form, have become depicted in drawings and modelings in the form of breasts as an isolated body part.

Among koema praying for a good supply of milk, there are items that give even clearer expression to that wish. Figure 11 is a koema from Hotei shrine at Shitennōji temple in the city of Osaka, which is widely called the "expressing milk" koema. This has been variously classified as depicting the receiving of milk by a woman whose own supply is deficient and has trouble finding a donor, or as the giving of milk to another by a woman with an excessive flow (Iwai, 1974). It may thus be described as responding to a variety of situations involving individual women with regard to breast milk. Such koema are of interest in that they do not simply depict or model the breasts, but give expression to the concrete act of breast milk flowing freely, and thus clearly show the wish for that result.

\subsection{Koema for Female Genitals}

Incidentally, ema for "ailments of the lower half of the female body" are expressed

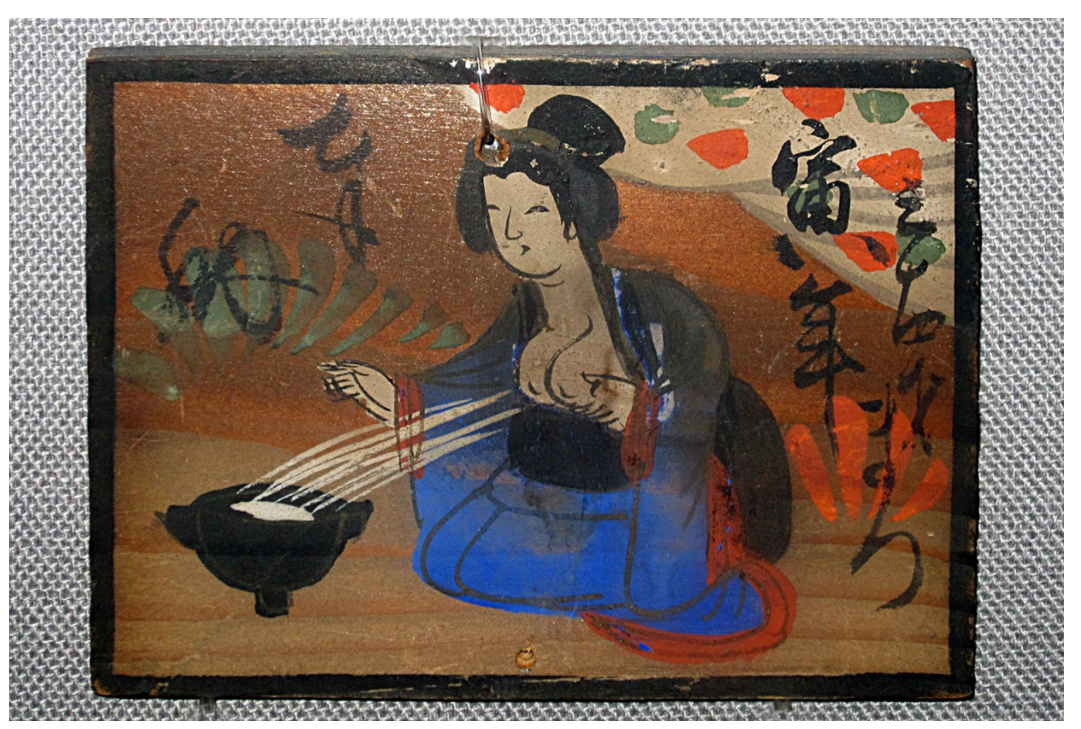

Figure 11. A koema related to wishes for a sufficient supply of milk, from Hotei shrine at Shitennōji temple in the city of Osaka. (In the collection of Tenri University Sankokan Museum.) 
with images of kimono, but was there no notion of drawing ema in which female genitals per se were depicted? Searching koema with that thought in mind, I found one with a large-scale drawing of female genitalia (Figure 12) among items held in storage at Tenri University Sankokan Museum. The ink inscription on the front reads "Offering, Omata Village in Ashikaga of Shimotsuke, Tomita Wa," with the name of the donor and her village carefully recorded. This type of realistic depiction of a bodily part shares the same mode of expression with breast koema, of drawing the relevant portion in isolation from the rest of the body. As koema praying for recovery of ailments of the lower part of women's body, in addition to this realistic depiction of female genitals, there are those showing a woman's legs protruding beneath a white or red waistcloth or kimono (Figure 7, right), and these are also extremely striking. When we consider that "ailments of the lower half of the female body" of course included venereal disease, these koema are expressions of pressing desires. Understandably, the pattern using kimono as symbolic expression was favored more, and great numbers of these were used. Perhaps a sense that if at all possible it was best to avoid hanging up overly realistic depictions of female genitals on shrine precincts was at work.

\section{Analysis: Expressions of Body Parts Seen in Koema and Bodily Motif Yokai}

Thus far I have traced out bodily expressions drawn on koema, paying attention to the folk religious practice still followed in contemporary Japan of offering these items at shrines and temples. I have introduced examples with eyes, breasts, and female genitals, but there are also koema on which hands and penises are drawn. These body parts have the characteristics of easily experiencing troubles such as illness or injury, and unlike diseases of the internal organs, the

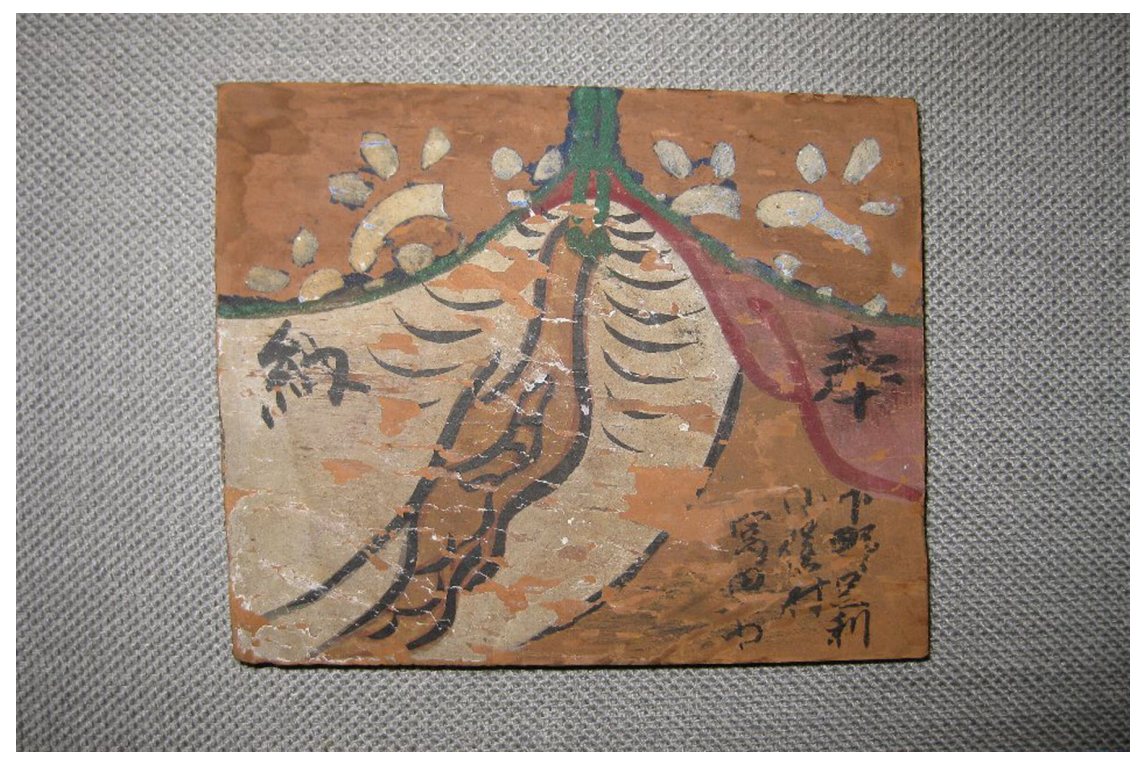

Figure 12. A koema depicting female genitals. (In the collection of Tenri University Sankokan Museum.) 
afflicted portions are readily visible and their symptoms quickly recognized. Accordingly they may be regarded as easily rendered into depictions.

Next I would like to consider the mode of expression for bodily parts seen in koema. In each case, even when the donor's name is inscribed, individual characteristics of the donor's body have been erased from the expression, and the body part itself depicted or modeled in isolation. Also, the mode of expression has become formalized. In the case of the eyes, for example, even if only one eye is afflicted, the drawing of a single eye on a koema is rare, and it is noteworthy that in most cases a single or multiple pairs of eyes are depicted. These ema drawn with large numbers of eyes vividly remind us of the dodomeki (Figure 3) and mokumokuren (Figure 4) drawn by Toriyama in the latter half of the eighteenth century.

Also, while devices such as symbolic expression through a kimono are seen in koema for female genitals, when women's private parts are openly depicted, they are given large-scale, realistic expression. Such depictions are reminiscent of the treatment of private parts in images of intercourse seen in shunga prints, which were popular in the Edo period. Further, breasts are also emphasized through overly full shapes. Regarding breasts, female genitals, or penises, to see whether there are yokai based on these body parts I checked the Paintings of Strange Phenomena and yōkai (Ghosts, Monsters, Spirits) database maintained by the International Research Center for Japanese Studies

(http://www.nichibun.ac.jp/YoukaiGazouMenu/). I learned thereby of the existence of yokai based on female genitalia and penises, and others based on combinations of those body parts. Yet while there are yokai of women in opened kimonos with their breasts visible, I could not find yokai consisting of breasts alone. This perhaps suggests that somebody parts more easily lend themselves to the creation of yokai based on alterations to the human body.

In this manner, depicting large numbers of eyes lined up on koema, or drawing genitalia or breasts in exaggerated fashion, was a way of praying for recovery from disease while expressing the afflicted body part in readily understandable form. That mode of expression may be considered as having been linked at its base with the one used for the creation of yokai based on the body. The offering of koema also became popular in the latter part of the Edo period, and at the start of the nineteenth century in particular, around the Bunka and Bunsei eras (1804-1830), it is said that professional ema artists drew them in great numbers (Iwai, 1974). While empirical research is of course necessary with regard to the relation between pictures of yokai, which gained popularity from the end of the eighteenth century, and drawings on koema, we can infer that when yokai were created based on the human form, and when depictions or modelings of the body were made in folk religious practices, the same manner of creative ability using the body was at work. It will be necessary to continue giving consideration to whether this creative use of the body persists in the present day, and also to what people have continued to express using yokai as a medium. While including Japanese folk religion in this manner, I wish to continue research that will 
clarify views of the body and the supernatural held in the past by people who created and enjoyed yokai, in other words research on Japanese culture through yokai as a window which enables us to clarify the creative power of people of those times.

\section{Acknowledgements}

Regarding the preparation of this contribution, I would like to express my sincere appreciation to Walter Edwards for his English translation. I also give sincere thanks to Prof. Komatsu Kazuhiko, Director of the International Research Center for Japanese Studies, and to my colleagues in the Department of History and Culture Studies at Tenri University for their valuable comments on the content of this work at the Tenri University Archaeology and Folklore Studies Forum, "Searching Phantoms and Yokai in the World Through Objects and Images," held in Tokyo in June 2016.

\section{References}

Corbin, A., Courtine, J.-J., \& Vigrello, G. (2005). Histoire du corps: Vol. 1. De la Renaissance aux Lumières [History of the Body: Vol. 1. From the Renaissance to the Enlightenment]. Paris: Seuil.

Foster, M. D. (2009). Pandemonium and Parade: Japanese Monsters and the Culture of Yōkai. Berkeley, CA: University of California Press.

Foster, M. D. (2015). The Book of Yökai: Mysterious Creatures of Japanese Folklore. Oakland, CA: University of California Press.

Iijima, Y. (2001). Hitotsume kozō to hyōtan: Sei to gisei no fōkuroa [Hitotsume Kozō and Gourds: The Folklore of Gender and Sacrifice]. Tokyo: Shin'yōsha.

Iikura, Y. (2010). Nippon no kappa no shōtai [The True Nature of Japanese Kappa]. Tokyo: Shinjinbutsu Ōraisha.

Iikura, Y., \& Ichiyanagi, H. (Eds.) (2016). Kaii o miseru [Mesmerizing Phantoms]. Tokyo: Seikyusha.

Iwai, H. (1974). Ema. Tokyo: Hosei University Press.

Kagawa, M. (2005). Edo no yōkai kakumei [The Edo Yokai Revolution]. Tokyo: Kawade Shobo Shinsha.

Komatsu, K. (1994). Yōkaigaku shinkō: Yōkai kara miru Nihonjin no kokoro [New Theory in Yokai Studies: The Japanese Mind Seen through Yokai]. Tokyo: Shōgakukan.

Komatsu, K. (2008). Hyakki yagyō emaki no nazo [Mysteries of Hyakki Yagyō Emaki]. Tokyo: Shueisha.

Kuroda, H. (1986). Kyōkai no Chūsei shōchō no Chūsei [The Medieval Period of Boundaries and Symbols]. Tokyo: University of Tokyo Press.

Tenri University Department of History and Culture (Ed.) (2016). Mono to zuzō kara saguru yōkai, kaijū no tanjō [Searching the Birth of Yokai and Monsters through $\mathrm{Ob}$ jects and Images]. Tokyo: Bensei Publishing.

Toriyama, S. (2005). Gazu hakki yagyō zengashū [Complete Anthology of Illustrations from Illustrated Night Parade of One Hundred Demons]. Tokyo: Kadokawa.

Yasui, M. (2014). Kaii to shintai no minzokugaku: Ikai kara shussan to kosodate o toinaosu [The Folklore of Phantoms and Bodies: Reevaluating Childbirth and Childrearing from the Spirit World]. Tokyo: Serica Syobo. 
Yasui, M. (2015). Kaii no imēji o otte: Ubume to tengu o chūshin ni [Pursuing Images of Phantoms: Focusing on Ubume and Tengu]. In Tenri University Department of History and Culture (Ed.), Mono to zuzō kara saguru yōkai, kaii no sekai [Searching the World of Yokai and Phantoms through Objects and Images] (pp. 18-40). Tokyo: Bensei Publishing.

Yasui, M. (2016). Yōkai ga umareru toki: Hitotsume no yōkai [When Yokai Are Born: Single-Eyed Yokai]. In Tenri University Department of History and Culture (Ed.), Mono to zuzō kara saguru yōkai, kaijū no tanjō [Searching the Birth of Yokai and Monsters through Objects and Images] (pp. 63-69). Tokyo: Bensei Publishing.

Yasui, M. (2017). Minkan shinkō ni miru shintai no zuzōka, zōkeika: Yōkaiga no haikei o motomete [Depictions, Modelings of the Body Seen in folk Relition: Seeking the Background of Yokai Images]. In Tenri University Department of History and Culture (Ed.), Mono to zuzō kara saguru kaii, yōkai no tōzai [Searching Phantoms and Yokai in the World through Objects and Images] (pp. 109-136). Tokyo: Bensei Publishing.

Yumoto, K. (2003). Edo no yōkai emaki [A Picture Scroll of Edo Yokai]. Tokyo: Kobunsha.

\section{Submit or recommend next manuscript to SCIRP and we will provide best} service for you:

Accepting pre-submission inquiries through Email, Facebook, LinkedIn, Twitter, etc. A wide selection of journals (inclusive of 9 subjects, more than 200 journals)

Providing 24-hour high-quality service

User-friendly online submission system

Fair and swift peer-review system

Efficient typesetting and proofreading procedure

Display of the result of downloads and visits, as well as the number of cited articles

Maximum dissemination of your research work

Submit your manuscript at: http://papersubmission.scirp.org/

Or contact aa@scirp.org 